\title{
Lisansüstü Eğitimin Çalışanların İş Performansları Üzerindeki Etkisi: Beşeri Sermaye Teorisi Yaklaşımı
}

\author{
The Impact of Post-Graduate Education on Employees' Job Performance: \\ Human Capital Theory Approach
}

\author{
Yrd. Doç. Dr. Ceyda Maden Eyiusta - Yrd. Doç. Dr. Bengi Yanık Illhan
}

\begin{abstract}
Öz
Geçtiğimiz son beș sene içerisinde, Türkiye'de yüksek lisans ya da doktora derecesine sahip olan 15 yaşüstü kurumsal olmayan nüfus \% 68 artmıştır. Aynı zamanda, işgücü piyasasinda da lisansüstü derecelere sahip olan çalışanların oranı giderek artmaktadır. Temeli arz yanlı iktisada dayanan beşeri sermaye teorisine göre, kişilerin eğitim ve iş deneyimi yoluyla edindikleri yetenek ve bilgiler performanslarm olumlu yönde etkileyerek, işgücü piyasasında daha yüksek ücretler almalarına neden olur. Bu çalı̧̧mada, bireylerin lisansüstü eğitim almış olmaları ile performanslarına bağlı olarak aldıkları teşvik tedbiri (ikramiye, prim ve bahşişler) miktarı arasında anlamlı bir ilişki olup olmadığı sorgulanmıştır. Ayrıca, lisansüstü eğitim almış olmanın teşvik tedbirleri üzerindeki etkisinin kadin ve erkekler için farklılaşıp farklılaşmadığı incelenmiştir. Öne sürülen hipotezlerin test edilmesinde, Türkiye İstatistik Kurumu tarafindan uygulanan Hanehalkı Bütçe Anketleri mikro veri seti, 2003-2010 yılları baz alınarak kullanılmıştır. Bahsi geçen yılların toplam gözlem sayısı 357,966 olup çalışmanin örneklemi en az lisans derecesine sahip 20 yaş üstü 18,067 katılımcıdan oluşmaktadır.En küçük kareler yöntemi ile yapılan analizler sonucunda, yüksek lisans/doktora eğitimi almış olan kişilerin aldıkları teşvik tedbiri miktarının daha yüksek seviyede olduğu bulunmuştur. Çalışmanın bir başka bulgusu da, lisansüstü eğitim almış olmanın performansa dayalı teșvik tedbirleri bakımindan getirisinin, kadinlar ve erkekler için farklılaşmadığı yönündedir.
\end{abstract}

Anahtar Kelimeler: Lisansüstü Eğitim, Beşeri Sermaye Teorisi, Performans, Teşvik Tedbirleri

\begin{abstract}
In the last five years, non-institutional population aged 15 and older with a master's or doctoral degree increased by $68 \%$ in Turkey. The ratio of workers having post-graduate degrees has been increasing in the labor market as well. According to human capital theory which rests upon the supply-side economics, knowledge and abilities acquired by individuals are likely to increase job performance and bring about higher earnings in the labor market. In this study, the relationship between individuals' attainment of post-graduate education and the amount of their performance incentives (bonuses, premiums, and commissions) has been examined. Furthermore, this study investigates whether the attainment of a post-graduate degree influence the performance incentives of women and men differently. Hypotheses have been tested by using the micro dataset of 2003-2010 Household Labor Force Surveys, which have been conducted by Turkish Statistical Institute. In the selected years, the number of observations includes 357.966 individuals where the sample of the study consists of 18.067 participants who are over 20 years old and attained an undergraduate degree. Analyses that are based on least-square estimation method revealed that individuals who attained a master's or doctorate degree are provided with higher levels of incentives in the labor market. Additionally, the results showed that the return of post-graduate education in terms of performance-based incentives did not significantly differ between women and men.
\end{abstract}

Keywords: Post-Graduate Education, Human Capital Theory, Performance, Incentives

Yrd. Doç. Dr. Ceyda Maden Eyiusta, İstanbul Kemerburgaz Üniversitesi İİBF, ceyda.maden@kemerburgaz.edu.tr Yrd. Doç. Dr. Bengi Yanık İlhan, İstanbul Kemerburgaz Üniversitesi İİBF, bengi.ilhan@kemerburgaz.edu.tr 


\section{Giriş}

Türkiye'de her geçen yıl üniversite sayısı artmaktadır. Sayılarla ifade edecek olursak, 1982 yılında ülkemizde sadece 27 devlet üniversitesi varken (Günay ve Günay, 2011), 2013 yılına gelindiğinde bu sayı 69'u vakıf üniversitesi olmak üzere 179’a çıkmıştır (YÖK, 2013). Özellikle vakıf üniversitelerinin sayılarındaki dikkat çekici artış ve beşeri sermeyenin uluslararası düzeyde rekabetin bir numaralı gücü haline gelmesi yüksek lisans ve doktora programlarındaki artışı da beraberinde getirmiş; bu programlara olan ilgiyi toplumsal düzeyde attırmıştır. Geçtiğimiz son beş sene içerisinde, Türkiye'de yüksek lisans ya da doktora derecesine sahip olan 15 yaş üstü nüfus 1.7 kat artmıştır. 2008 yılında 320 bin kişi yüksek lisans ya da doktora derecesine sahipken, 2012'de bu sayı 539 bine çımıştır (TÜİK, 2013). Aynı zamanda, işgücü piyasasında da yüksek lisans/doktora derecesine sahip olan çalışanların oranı da artmaktadır. 2000 Hane Halkı Bütçe Anketi sonuçlarına göre, ankete katılan 15 yaş ve üstü kişiler arasında \% 0.02'si yüksek lisans ya da doktora derecesine sahipken; bu oran 2009 yllinda \% 0.05’e çıkmıştır.

Eğitimin ekonomideki rolünü açıklamak için kullanılan en eski yaklaşımlardan biri olarak kabul edilen Beşeri Sermaye Teorisi'ne Becker (1964) göre, kişilerin eğitim yoluyla edindikleri bilgi ve beceriler, verimliliklerini arttırarak, marjinal ürün değerlerini daha yüksek seviyelere çekmekte ve daha yüksek kazançlar elde etmelerini sağlamaktadır. İlköğretim, lise ve üniversite eğitiminden sonra yüksek eğitime devam eden bireyler, çalıştıkları kurumların kendilerine performanslarından ötürü hızlı bir kariyer yükselişi sağlayarak, potansiyellerinden faydalanma yoluna gideceklerini düşünmektedirler. Bu yükseliş, daha fazla firsat ve kazancı da beraberinde getirmektedir.

Bu noktada, akademik anlamda incelenmesi gereken önemli konulardan bir tanesi, bireylerin, lisans eğitimlerinin ardından yüksek lisans veya doktora yaparak beșeri sermayelerine yaptıkları yatırımın performansları üzerinde gerçekten etkili olup olmadığıdır. Kamu sektöründe ve bazı özel sektör kuruluşlarında çalışanlar, yüksek lisans veya doktora derecesine sahip oldukları takdirde performanslarına bakılmaksızın maaş artışıyla ödüllendirilmektedir. Dolayısıyla, bireylerin beşeri sermayelerine yaptıkları yatırımın performansları üzerindeki gerçek etkisini sadece maaş artışı verilerine bakarak anlamak zordur. $\mathrm{Bu}$ durum ampirik araştırmalarda, maaş artışı dişında performanstaki artışı yansıtan başka göstergelerin de kullanılmasını önemli kılmaktadır.

Çalışmada sorgulanan diğer bir konu, lisansüstü eğitim almış olmanın teşvik tedbirleri üzerindeki etkisinin kadın ve erkekler için farklılaşıp farklılaşmadığıdır. Mevcut çalışmalar, kadınların işgücü piyasasında cinsiyete dayalı ayrımcllıkla karşı karşıya kalarak, erkeklerle aynı eğitim seviyesine sahip olmalarına rağmen, daha düşük ücret aldıklarını göstermektedir (Kasnakoğlu ve Dayığlu, 1997; Koçak, 1999; Çolak ve Ardor, 2001). Eğitim-gelir ilişkisine bakıldığında ise eğitimin getirisinin kadınlar ve erkekler için aynı olmadığ 1 görülmektedir. Ancak bu çalışmaların hiçbirinde, özellikle lisansüstü eğitim konusuna odaklanılarak, lisansüstü eğitim almış olmanın kadın ve erkeklerin iş performansları ve aldıkları teşvik tedbirleri miktarı üzerindeki etkisi incelenmemiştir.

Yukarıda bahsi geçen noktalar göz önünde bulundurularak, bu çalışma kapsamında, çalışanlara işverenleri tarafindan verilen ve sadece bireysel performans ve üretim seviyeleriyle şekillenen teşvik tedbirleri (ikramiye, prim ve bahşişler) (Lawler, 1990, 1992) temel performans göstergeleri olarak kullanılmış ve bireylerin lisansüstü eğitim almış olmaları ile aldıkları teşvik tedbiri miktarı arasında anlamlı bir ilişki olup olmadığ 1 sorgulanmıştır. Ayrıca, Beşeri Sermaye Teorisi'nin varsayımları ışığında, lisansüstü eğitimi tamamlamış olmanın kadın ve erkek çalışanların iş performansları ve aldıkları teşvik tedbiri miktarları üzerinde fark yaratıp yaratmadığı incelemeye alınmıştır.

Bu çalışma, giriş bölümü dâhil toplam beş bölümden oluşmaktadır. İkinci bölümde çalışmanın teorik alt yapısı anlatılacak ve konuyla ilgili mevcut çalışmalardan bahsedilecektir. Üçüncü bölümde ise veri seti tanıtılmış; araştırma yöntemi ve ampirik bulgular sunulmuştur. Dördüncü ve son bölümde çalışmanın sonuçları tartışılmıştır.

\section{Teorik Alt Yapı ve Yazın}

\section{Beşeri Sermaye Teorisi}

Beşeri Sermaye Teorisi, eğitimin ekonomideki rolünü açılamak için kullanılan en eski yaklaşımlardan biri olarak kabul edilmektedir (Öztürk, 2005). Ekonomik gelişme süreci içerisinde insan faktörünün rolünü açıklamaya yönelik olarak geliştirilen beșeri 
sermeye kuraminda beşeri sermaye, kişiye mal olmuş bilgi, beceri ve kazanılmış olan diğer niteliklerin değeri olarak tanımlanmıştır (Schultz, 1971). Örgütsel düzeyde ise beşeri sermaye, "bireylerin işlerine yatırdıkları bilgi, vasıf, deneyim, yaratıcılık, enerji ve gayretin ortak toplamı"nı ifade eder (Weatherly, 2003; s. 1). Beşeri sermaye teorisinde, insana yapılan yatırımlar sayesinde kalkınma sürecinin kısalabileceği ileri sürülmüştür (Schultz, 1971). Buna göre, bir ekonomide belli bir dönemde üretilen mal ve hizmet miktarı, kişisel kazançlar ve insana yapılan yatırımlar arasında doğrusal bir ilişki vardır (Özturk, 2005). İnsana yapılan yatırım arttıkça ulusal gelir ve kişisel kazanç da artmaktadır. Ayrıca, sosyo-ekonomik kalkınmanın gerçekleştirilmesinde ve yapısal değişimin sağlanmasında da beşeri sermayenin en az fiziksel sermaye kadar önemli bir rolü vardır. Buna göre, iktisadi kalkınmanın hızlandırılabilmesi için emeğin beşeri sermaye yatırımlarının artırılması gerekmektedir (Taban ve Kar, 2006). Bu yatırımların en önemlisi ise eğitim harcamalarıdır.

Yukarıda bahsedilen ilişkiler göz önüne alındığında, beşeri sermaye teorisi, özellikle eğitim ve çalışma ekonomisi araştırmalarında önemli bir yere sahiptir. Temeli arz yanlı iktisada dayanan beşeri sermaye teorisine göre, kişilerin eğitim ve iş deneyimi yoluyla edindikleri yetenek ve bilgiler performanslarını olumlu yönde etkileyerek, işgücü piyasasında daha yüksek ücretler almalarına neden olur (Becker, 1964). Bu noktada beşeri sermaye teorisi, marjinal verimlilik teorisi ile de uyumludur. Diğer tüm faktörler sabit tutulduğunda (cateris peribus), daha verimli çalışan işgücü, daha yüksek ücret geliri elde etmektedir. İşgücü veriminin attırılması için de daha fazla eğitim yatırımına gereksinim vardır (Ünal, 1993). Buna göre, eğitim sistemi içerisinde izlenmesi gereken politikalardan biri, ekonomik gelişim hedeflerine bağlı olarak, bugüne ve gelecekteki iş alanlarına yönelik, meslek elamanlarını yetiştirmek üzere eğitim programları geliştirmektir (Öztürk, 2005). Bu şekilde ekonominin farklı sektörlerinde ihtiyaç duyulan nitelikli işgücü yetiştirilmiş olacaktır (Öztürk, 2005).

Bireysel düzeyde de eğitimin farklı getirilerinden bahsetmek mümkündür. Mincer (1993), daha yüksek eğitimli çalışanların, daha az eğitimli çalışanlara göre üç önemli avantaja sahip olduğundan bahsetmiştir. $\mathrm{Bu}$ avantajlar, daha yüksek gelir, daha düşük işsiz kalma olasılığı (daha istikrarlı istihdam) ve yüksek gelir dilimlerinde daha yüksek hareketlilik (mobilite) olarak sıralanmaktadır. Eğitim, bireylere yeni bilgi ve beceriler kazandırarak verimliliklerini arttırmaktadır. Bu varsayım ışı̆ı̆ında, daha eğitimli çalışanların marjinal ürün değerleri de daha yüksek olacak ve bu kişiler daha yüksek kazanç elde edebileceklerdir (Mincer, 1993; Psacharopoulos ve Woodhall, 1994). Eğitimin temel avantajlarından bir diğeri de, yüksek eğitim seviyelerinde (örn: yüksek lisans ve doktora) işsizlik riskinin düşmesi ve "işsiz kalma süresi"nin kısalmasıdır. Yüksek eğitimli çalışanlar, işsiz kaldıklarında daha kısa sürede iş bulabilmekte; iş arama ve iş değiştirme süreçlerinde de düşük eğitimli bireylere göre daha etkin davranabilmektedirler (Mincer, 1993). Özellikle ilk durum, işsizliğin bireysel maliyetlerini önemli oranda düşürmektedir (Çalışkan, 2007).

Beşeri sermaye teorisinin yukarıda anlatılan temel varsayımları bugüne kadar farklı alanlardaki (örn: eğitim ekonomisi, çalışma ekonomisi, endüstriyel organizasyon, insan kaynakları yönetimi) çalışmalara yön vermiştir. Aşağıdaki bölümde bu çalışmalardan bahsedilmekte ve ardından bu çalışmanın hipotezleri sunulmaktadır.

\section{Eğitimin Performans ve Gelir Üzerindeki Etkileri}

Eğitimin bireysel performans üzerindeki etkilerini inceleyen önceki çalışmalar incelendiğinde, tamamlanan eğitim seviyesi ile bireysel performans arasındaki ilişkiye bakan çok az çalışma olduğu görülmüştür. Blundell vd. (1999) bu durumun nedenini şu şekilde açıllamışlardır: Resmi eğitim seviyesi, eğitim sistemi içerisinde kazanılan yeteneklerle, deneyimler yoluyla kazanılan yetenekleri kapsar. Eğitim yoluyla edinilen yeteneklerle, deneyimler yoluyla kazanilan becerileri birbirinden ayırmak çok zor olduğu için tek başına eğitimin bireysel performans üzerindeki etkisini araştıran çalışmalar da sınırlıdır.

Uluslararası boyutta yürütülmüş mevcut çalışmalarda, eğitimin kişinin genel zekâ seviyesini arttırdığı ve buna bağlı olarak işle ilgili bilgi ve becerilerini geliştirerek bireysel performansa katkıda bulunduğu öne sürülmüştür (Stark vd. 2011). Kanfer ve Ackerman'a (2004) göre zekâ, akışkan ve kristal olmak üzere iki şekilde ortaya çıkar. Akışkan zekâ, kısa süreli bellek, soyut akıl yürütme, dikkat, karmaşık bilgiyi işleme kapasitesine karşıllk gelmektedir. Kristal zekâ ise bireyin mesleki ya da meslek dışı konulardaki-alanlardaki genel bilgisini, kelime haznesinin genişliğini ve sözlü anlama becerisini ifade eder. Önceki araştırmalar, eğitim seviyesi daha yüksek olan bireylerin hem 
akışkan hem de kristal zekâsının daha yüksek olduğunu göstermiştir (Ceci, 1991; Neisser vd., 1996). Benzer şekilde, bilgi de, bildirime dayalı ve yöntemsel olmak üzere iki şekilde açığa çıkar. Bildirime dayalı bilgi, bulgulara, kurallara ve prensiplere dair uzmanlığ ifade ederken; yöntemsel bilgi bildirime dayalı bilginin pratiğe uygulanmasına karşılık gelir (Ree vd., 1994). Bu noktada eğitim, bireylerin kendilerine verilen görevleri doğru bir şekilde yapmaları için gerekli olan bildirime dayalı ve yöntemsel bilgiyi sağlamakta önemli bir rol oynar (Ng ve Feldman, 2009). Tüm bu önermeler doğrultusunda mevcut çalışmalar, eğitimin bireysel performansı arttırdığını göstermiştir (Hunter ve Hunter, 1984; Ng ve Feldman, 2009; Stark vd., 2011). Özel olarak lisansüstü eğitimin bireysel performansı üzerindeki etkisini inceleyen çalışmalarda da, yüksek lisans ve üstü eğitim seviyesine sahip olmanın farklı performans göstergelerini (örn. iş performansı, terfi olasılığı, maaş artış oranı) olumlu yönde etkilediği ortaya koyulmuştur.

Yukarıda bahsi geçen çalışmalara ilk örnek, Judge vd.nin 1995 yılında Amerika'daki 1,388 üst düzey yönetici ile yaptıkları çalışmadır. Bu çalışmada, farklı demografik, motivasyonel, örgütsel, sektörel/bölgesel ve beşeri sermaye ile ilgili faktörlerin yöneticilerin kariyer başarıları üzerindeki etkileri sorgulanmıştır. Beşeri sermayeyle ilgili faktörler arasında yer alan eğitim seviyesi ile kariyer başarısı arasındaki ilişki incelendiğinde, ortalama 20 senelik kariyer geçmişine sahip olan yöneticiler arasında lisansüstü eğitim almış yöneticilerin, sadece lisans derecesine sahip yöneticilerden kümülatif olarak yaklaşık 150,000 dolar daha fazla kazanç elde ettikleri bulunmuştur. Aynı çalışmada, Amerika'da itibarı yüksek bir üniversitede lisans ve yüksek lisans eğitimi almı̧̧ iki yöneticinin performansa dayalı yıllık kazançları da karşılaştırılmış; bahsi geçen üniversitede lisans eğitimini tamamlamış, uluslararası platformlarda deyimi olmayan bir yöneticinin, aynı üniversiteden yüksek lisans derecesi almı̧ ve uluslararası deneyime sahip bir yöneticiye göre 54,434 dolar daha az kazandığı tespit edilmiștir. Yüksek lisans eğitimi ile iş performansı üzerindeki ilişkiyi askeriyede görevli memurların terfi bilgilerini içeren 2,353 kişilik bir mikro veri seti üzerinden inceleyen başka bir çalışmada, Bowman ve Mehay (1999) yüksek lisans eğitimine sahip memurların işlerindeki performanslarının ve terfi olasılıklarının daha yüksek olduğu sonucuna varmışlardır. Benzer şekilde, tamamlanan eğitim seviyesi, terfi olasılıkları ve elde edilen kazanç arasındaki ilişkiye odaklanan Spiler- man ve Lunde (1991), yüksek lisans derecesine sahip olmanın, bireylerin terfi olasılıkları ve ücret artışları üzerinde olumlu bir etki yarattığını bulmuşlardır. James ve Alsalam (1993) ise, yüksek lisans derecesinin ötesinde elde edilen derecelerin, bireylerin gelecekteki kazançlarını arttırdığını ortaya koymuşlardır. Son olarak, Hurley-Hanson vd.'nin (2005) çalışması, tamamlanan eğitim seviyesi ile terfi olasılıkları arasındaki anlamlı ilişkiyi desteklemiştir.

Türkiye'de yapılan çalışmalarda "gelir", beşeri sermaye teorisinin ana prensiplerine uygun olarak, bireysel verimliliğin en temel göstergesi olarak ele alınmış ve sınırlı sayıdaki ampirik çalışmada eğitim seviyesi ile gelir arasındaki ilişki incelenmiştir. Dayıŏ̆lu ve Kasnakoğlu (1997) çalışmalarında, Devlet İstatistik Enstitüsü (DİE) 1994 Hanehalkı Gelir ve Tüketim Anketi verilerine dayanarak eğitim-gelir ilişkisini cinsiyet bazında incelemiş ve çalışmanın önemli sonuçlarından biri olarak eğitimin gelirin önemli bir belirleyicisi olduğunu vurgulamışlardır ${ }^{1}$. Kentsel ücretliler için benzer bir çalışma, Tansel (1994) tarafından yapılmıştır. Bu çalışmada da eğitim seviyesine bağlı olarak getirinin arttığı sonucu elde edilmiştir. Benzer şekilde, Tansel (2002), 1989 Nisan ve Ekim aylarına ait DİE Hanehalkı İşgücü Anketi verilerini kullanarak eğitimin getirisinin eğitimin süresine bağlı olarak arttığı yönünde bulgular elde etmiştir. İl bazında yapılan farklı araştırmalarda da, eğitim seviyesi yükseldikçe kişisel kazançların da anlamlı bir şekilde yükseldiği bulunmuştur (Özcan vd., 2003; Sarı, 2002; Çalışkan, 2007).

Giriş bölümünde bahsedildiği üzere yazındaki mevcut çalışmalardaki en önemli eksiklik, toplam maaş ya da kazancın bireysel performansin en temel göstergesi olarak benimsenmesidir. Oysaki bireylerin beşeri sermayelerine yaptıkları yatırımın performansları üzerindeki gerçek etkisini sadece maaş artışı verilerine bakarak anlamak zordur. Çünkü özellikle kamu sektöründe ve bazı özel sektör kuruluşlarında çalışanlar, lisansüstü eğitim derecelerine sahip oldukları takdirde, performanslarına bakılmaksızın maaş artışıyla ödüllendirilmektedir. Bu durum, ampirik araştırmalarda, maaş artışı dışında performanstaki artışı yansıtan başka göstergelerin de kullanılmasını önemli ve gerekli kılmaktadır. Bu çalışmada, maaş verisinin yanı sıra çalışanlara işverenleri tarafından verilen ve sadece performans ve üretim seviyeleriyle

1 Türkiye istatistik Kurumunun adı 1994 yılında adı Devlet İstatistik Enstitüsü (DİE) olarak geçmektedir 
belirlenen (Lawler, 1990, 1992) teșvik tedbirleri (ikramiye, prim ve bahşişler) bireysel performans göstergeleri olarak kullanılmıștır. Ayrıca, mevcut yazına bakıldığında, Türkiye'de eğitim-gelir ilişkisini inceleyen birçok çalışma olmasına rağmen, özellikle yüksek lisans ve doktora eğitiminin bireysel performans ve teşvikler üzerindeki etkilerini inceleyen çalışmalara rastlanılmamıştır. Bu boşluğu doldurmak amaciyla ve lisansüstü eğitimin kişilerin işle ilgili bilgi ve becerilerini arttırarak bireysel performanslarına katkıda bulunacağı düşüncesinden hareketle çalışmanın ilk hipotezi aşağıdaki şekilde geliştirilmiştir. Hipotezde, yüksek lisans ya da doktora derecesine sahip olmanın teşvik tedbirleri üzerindeki etkisi, kıyas seviyesi olarak, lisans derecesine sahip olmanın etkisiyle karşlaştırılmıştır.

Hipotez 1: Yüksek lisans ya da doktora derecesine sahip olan çalışanların elde edecekleri teşvik tedbiri miktarı, lisans derecesine sahip olan çalışanlara k1yasla daha yüksektir.

\section{Cinsiyet Bazında Ücret Farklıkları ve Eğitimin Getirisi}

Eğitim ile gelir arasındaki ilişkiyi cinsiyet bazında inceleyen mevcut çalışmalarda öne çıkan en önemli konulardan biri, kadınların işgücü piyasasında cinsiyete dayalı ayrımcllıkla karşı karşıya kalarak, aynı eğitim seviyesine sahip erkeklerden daha düşük ücret almalarıdır. Özellikle gelişmiş ülkelerde bu konu ile ilgili birçok teorik ve ampirik çalışma yapılmış, genel olarak kadınların erkeklerden daha az kazandıkları ve daha düşük ücretli, geleceği olmayan mesleklerde yoğunlaştıkları görülmüştür (Bergmann, 1986).

Türkiyede yapılan çalışmaların sonuçları da, kadınların işgücü piyasasında cinsiyete dayalı ayrımcılıkla karşı karşıya kaldıklarını göstermiştir (Kasnakoğlu ve Dayıŏlu, 1997; Koçak, 1999; Çolak ve Ardor, 2001). Türkiyede işgücü piyasasında var olan ayrımcllığ ölçmeye çalışan ekonometrik araştırmalar, erkek çalışanlarla aynı beşeri sermaye donanımına sahip kadın çalışanların, erkeklerden daha düşük ücret aldıklarını ortaya çıkarmıştır (Kasnakoğlu ve Dayıoğlu, 1997; Kocak, 1999). Bu araștırmalar, kadınların erkeklere göre daha az ücret almalarının ve daha düşük statülü mesleklerde yoğunlaşmalarının, kendi beșeri sermaye donanımlarının yetersiz olmasından kaynaklandığını ileri süren beșeri sermaye teorisinin, ücret farklılıklarını açıklamada ne kadar yetersiz kaldığını göstermiştir.
İşgücü piyasasında cinsiyet ayrımcılığını açılamaya çalışan diğer neo-klasik modeller ise (örn: istatistiksel ayrımcılık modeli, duygusal ayrımcılık teorisi, aşırı kalabalıklaşma modeli), kadınlara karşı ülkemizde aşılması zor önyargılar ve stereotip düşüncelerin olduğunu ileri sürmüşlerdir (Palaz, 2002). Kadınların çalışma hayatında erkekler kadar güvenilir olmadıkları, evlendiklerinde ya da çocuk sahibi olduklarında yoğunlaşma problemi yaşayabilecekleri ve hatta işlerini terk edebilecekleri, asıl görevlerinin annelik ve eşlik olması gerektiği, çalışma hayatının ikincil öneme sahip olduğu bu ön yargılara örnek olarak verilebilir (Palaz, 2002). Türkiyede, işgücü piyasasında gerçek verimlilik ölçümlerine ulaşmak zor olduğundan işverenler, ücret dağılımı da dâhil olmak üzere işgücü ile ilgili çeşitli kararlarında bahsi geçen ön yargılarla hareket ederler. Ayrıca, mesleksel ayrımcillk (kadınların belli mesleklerde yoğunlaşması), kadınların erkek çalışanlarla eşit beşeri sermaye donanımına sahip olmalarına rağmen onlarla aynı piyasada rekabet edememelerine ve daha az ücret almalarına neden olmaktadır (Bergmann, 1986).

Ücretlerle ilgili cinsiyet ayrımcılığını açıklamaya çalışan bir başka yaklaşım da kurumcu yaklaşımdır. Kurumcu yaklaşım, piyasada birincil ve ikincil işler ayırımının var olduğunu, kadınların ve erkeklerin bu işler arasında bölümlendirildiğini öne sürer. Birincil işler, yüksek ücretlerin ödendiği ve ikramiyelerin ve terfi olanaklarının bol olduğu, işgücü devrinin düşük olduğu işlerdir (Palaz, 2002). İkincil işler ise, ücretlerin düşük, çalışma şartlarının kötü olduğu; ikramiyelerin olmadığ 1 ve işgücü devrinin çok yüksek olduğu işlerdir (Palaz, 2002). Kurumcu yaklaşımda kadınların genellikle ikincil işlerde istihdam edildiği, erkeklerin ise yüksek ücretli birincil işlerde çalıştı̆̆ vurgulanır.

Eğitim-gelir ilişkisini cinsiyet temelli inceleyen çalışmalara bakıldığında ise eğitimin getirisinin kadınlar ve erkekler için aynı olmadığı görülmektedir. Psacharopoulos ve Patrinos'un (2002) 98 ülke için yaptı$\breve{g} 1$ araştırmaya göre ilköğretimin kadınlara sağladığ getiri oranı \% 12.8 iken erkeklerde bu oran \% 20.1 olmaktadır. Benzer şekilde, yüksek öğretimin kadınlara sağladığ hemen hemen aynı seviyededir (\% 11). Orta öğretimde ise durum kadınlar lehinedir. Orta öğretimin kadınlara getirisi \% 18.4 iken, erkeklerde \% 13.9 seviyesinde kalmıştır. Tüm öğretim düzeylerinin ortalama getirisine bakıldığında incelenen oranlar kadın- 
lar için \% 9.8, erkekler ise \% 8.7 düzeyindedir. Buna göre, kadınların eğitimden elde ettikleri getiri erkeklere göre daha fazladır. Bu bulgular, Türkiye'de yapılan çalışmalarda da desteklenmiştir. Örneğin Tansel (1994)'in çalışmasında ilkokul ve ortaokul mezunu erkekler için eğitimin getirisinin kadınlara göre daha düşük olduğu sonucuna varılmıştır. Aynı konu, Üçdoğruk, Özcan ve Özcan (2000) tarafından İstanbul, Malatya, Adana ve Diyarbakır illeri için incelenmiş; erkekler için eğitimin getirisinin gelişmişlik düzeyine bağlı olarak \% 6 ile \% 8 arasında değiştiği, kadınlar için ise aynı getirinin Malatya ve Diyarbakır için \% 12, İstanbul için \% 10 ve Adana için ise $\% 7$ olduğu görülmüştür. Benzer şekilde, gelişmekte olan ülkelerde kadın eğitiminin ekonomik büyümeye katkısını inceleyen ekonometrik bir çalışmada eğitimin kadınlara sağladığı getirinin, erkeklere göre daha yüksek olduğu sonucuna ulaşılmıştır (Özpolat ve Yıldırım, 2009).

Eğitim ve gelir seviyesi arasındaki ilişkiyi açıklığa kavuşturmaya yönelik olan mevcut çalışmalar, iki konuda eksik kalmaktadır. Birincisi, bu çalışmalar ücretlerdeki ayrımcılı̆̆g ölçmeye çalışırken, teşvik tedbirleri gibi doğrudan bireysel performansı yansitan göstergeler üzerinde durmamışlardır. Bir başka deyişle, tamamlanan eğitim seviyesinin kadın ve erkeklerin bireysel performansları üzerinde farklı etkiler yaratıp yaratmadığını; bireysel performansa bağlı olarak alınan teşvik tedbirleri üzerine yoğunlaşarak incelememişlerdir. İkincisi, mevcut çalışmalar, emeğin verimliliğini arttırmada büyük bir öneme sahip olan yüksek eğitimin (Unay, 1982; Engin, 1996; Öztürk, 2005), özellikle de lisansüstü eğitimin, performansa dayalı ücretler bakımından getirisinin, kadınlar ve erkekler için farklılaşıp farklılaşmadığını sorgulamamışlardır. Bu çalışma kapsamında, lisansüstü eğitim almış olmanın kadın ve erkeklerin bireysel yetkinliklerini ve buna bağlı olarak gelişen performans göstergelerini benzer oranda etkileyeceği görüşü benimsenmiştir. Önceki çalışmalar, eğitimin getirisinin ilköğretim, lise ve üniversite seviyelerinde kadınlar lehine geliştiğini göstermiş olsalar da; yüksek lisans ve doktora gibi daha üst eğitim seviyelerinde, bireylerin kendi beşeri sermayelerine yaptıkları yatırımın kadın ve erkekler için benzer performans getirileri doğuracağı düşünülmektedir. Bu önermenin arkasındaki bir başka varsayım, performansın en

Tablo 1. Öğretim Yılı ve Eğitim Seviyesine Göre Okullaşma Oranı

\begin{tabular}{|c|c|c|c|}
\hline OkullaşmaOranı (Net) & $1997 / 1998$ & $2004 / 2005$ & $2011 / 2012$ \\
\hline \multicolumn{4}{|l|}{ Toplam } \\
\hline İlköğretim & $\% 84.74$ & $\% 89.66$ & $\% 98.67$ \\
\hline Ortaöğretim & $\% 37.87$ & $\% 54.87$ & $\% 67.37$ \\
\hline Yükseköğretim & $\% 10.25$ & $\% 16.60$ & $\% 35.51$ \\
\hline \multicolumn{4}{|l|}{ Kadın } \\
\hline İlköğretim & $\% 78.97$ & $\% 86.63$ & $\% 98.56$ \\
\hline Ortaöğretim & $\% 34.16$ & $\% 50.51$ & $\% 66.14$ \\
\hline Yükseköğretim & $\% 9.17$ & $\% 15.10$ & $\% 35.42$ \\
\hline \multicolumn{4}{|l|}{ Erkek } \\
\hline İlköğretim & $\% 90.25$ & $\% 92.58$ & $\% 98.77$ \\
\hline Ortaöğretim & $\% 41.39$ & $\% 59.05$ & $\% 68.53$ \\
\hline Yükseköğretim & $\% 11.28$ & $\% 18.03$ & $\% 35.59$ \\
\hline
\end{tabular}

Kaynak:Türkiye İstatistik Kurumu (TÜIK), Öğretim Yllı ve Eğitim Seviyesine Göre Okullaşma Oranı. 2012. 
temel göstergelerinden biri olarak kabul edilen teşvik tedbirlerinin dağıtımında daha objektif ve görünür ölçütler (örn: satış miktarı, üretim miktarı, firmaya kazandırılan müşteri sayısı) dikkate alındığı için maaşlarda görülen cinsiyet ayrımcılığının performansa dayalı ücretlerin belirlenmesinde etkin rol oynayamayacağıdır. Bu düşüncelerden hareketle, çalışmanın ikinci hipotezi aşağıdaki şekilde belirlenmiştir:

Hipotez 2: Yüksek lisans ya da doktora derecesine sahip olmanın elde edilen teşvik tedbiri miktarı üzerindeki etkisi, kadın ve erkek çalışanlar arasında anlamlı bir fark göstermez.

\section{Türkiye'deki Eğitim Sistemi ve Seçilmiş} İstatistikler

Çalışmanın veri setini tanıtmadan önce Türkiye'deki eğitim sistemini tanıtmakta ve eğitimle ilgili bazı istatistiksel verileri paylaşmakta fayda görülmektedir. Türkiye'de eğitim sisteminin resmi (formal) ve resmi olmayan (non-formal) eğitimden oluşan ikili bir yapısı vardır. Resmi eğitim okul öncesi eğitim ile başlar ve ilköğretim, ortaöğretim (genel ve mesleki) ve yükseköğretim ile devam eder. Resmi olmayan eğitim ise halk eğitim, çıraklık eğitimi ve uzaktan eğitim gibi eğitim modüllerinden oluşmaktadır.

Tablo 2. Eğitim Durumuna ve Yıllara Göre İşgücü Durumu (15+ yaş)

\begin{tabular}{|c|c|c|c|}
\hline Işgücündeki Oran (15+ yaş) & 1998 & 2005 & 2012 \\
\hline \multicolumn{4}{|l|}{ Toplam } \\
\hline Okuma-yazma bilmeyen & $\% 9$ & $\% 5$ & $\% 4$ \\
\hline Okuma-yazma bilen fakat bir okul bitirmeyen & $\% 3$ & $\% 4$ & $\% 5$ \\
\hline İlkokul / İlköğretim & $\% 55$ & $\% 46$ & $\% 45$ \\
\hline Ortaokul veya dengi meslek okulu & $\% 10$ & $\% 11$ & $\% 8$ \\
\hline Lise & $\% 16$ & $\% 22$ & $\% 20$ \\
\hline Yüksekokul veya fakülte & $\% 7$ & $\% 12$ & $\% 18$ \\
\hline \multicolumn{4}{|l|}{ Kadın } \\
\hline Okuma-yazma bilmeyen & $\% 19$ & $\% 13$ & $\% 10$ \\
\hline Okuma-yazma bilen fakat bir okul bitirmeyen & $\% 3$ & $\% 6$ & $\% 6$ \\
\hline İlkokul / İlköğretim & $\% 50$ & $\% 40$ & $\% 41$ \\
\hline Ortaokul veya dengi meslek okulu & $\% 5$ & $\% 6$ & $\% 4$ \\
\hline Lise & $\% 14$ & $\% 18$ & $\% 16$ \\
\hline Yüksekokul veya fakülte & $\% 9$ & $\% 17$ & $\% 23$ \\
\hline \multicolumn{4}{|l|}{ Erkek } \\
\hline Okuma-yazma bilmeyen & $\% 5$ & $\% 2$ & $\% 2$ \\
\hline Okuma-yazma bilen fakat bir okul bitirmeyen & $\% 3$ & $\% 4$ & $\% 4$ \\
\hline İlkokul / İlköğretim & $\% 57$ & $\% 47$ & $\% 46$ \\
\hline Ortaokul veya dengi meslek okulu & $\% 12$ & $\% 13$ & $\% 10$ \\
\hline Lise & $\% 16$ & $\% 23$ & $\% 22$ \\
\hline Yüksekokul veya fakülte & $\% 7$ & $\% 11$ & $\% 16$ \\
\hline
\end{tabular}

Kaynak: TÜİK. İşgücü İstatistikleri, 1988-2012 
Türkiye’de 1997/1998 eğitim-öğretim yılından itibariyle 8 yıllık zorunlu eğitim uygulamasına geçilmiş ve bu yeni uygulamayla birlikte eğitim seviyesi ve cinsiyete göre okullaşma oranı artmıştır. Tablo 1'de görüldügü üzere 2011-2012 öğretim yılı itibari ile toplam okullaşma oranı ilköğretimde \%99, ortaöğretimde \% 67, yükseköğretimde ise \% 36 seviyesine çıkmıştır (TÜİK, 2012). Cinsiyet temelinde okullaşma oranlar1na bakıldığında da aynı yükseliş gözlemlenmektedir.

Eğitim durumuna ve ylllara göre 15 yaş üstü nüfusun işgücü istatistikleri incelendiğinde ise en çok dikkat çeken nokta Türkiye'de hem toplam işgücü, hem de ayrı ayrı kadın ve erkek işgücü içerisinde yüksekokul ve fakülte mezunlarının oranın giderek artmasıdır (Tablo 2). Bu durum işgücüne dâhil 15 yaş üstü nüfus içerisinde yükseköğretime verilen önemin giderek arttığını ve bireylerin eğitim seviyesi anlamında beşeri sermayelerine daha fazla yatırım yaptıklarını göstermektedir. 15 yaş üstü nüfusun eğitim durumuna ve yıllara göre istihdam istatistikleri de işgücü istatistikleri ile aynı doğrultudadır. 1998 yılında istihdam edilen 15 yaş üstü toplam nüfusun \% 7'si yüksek okul ya da fakülte mezunuyken (kadınlarda \% 8, erkeklerde \% 7), 2012 yılında bu oran \% 18’e (kadinlarda \% 22, erkeklerde \% 17) çıımıştır (TÜİK, 2012). Bu verilerde görüldüğü üzere istihdam edilen kadınlar arasında yüksek eğitim alanların oranı (\% 22) aynı eğitimi alan erkeklerin oranından daha fazladır (\% 17). Buna göre istihdam edilmede, kadınlar için eğitim seviyesinin erkeklere göre daha etkili olduğu söylenebilir.

\section{Veri Seti ve Ampirik Uygulama}

\section{Veri Seti}

Bu çalışmada. 2003-2010 yıllarını kapsayan ve her yıl, Türkiye İstatistik Kurumu tarafından yayınlanan Hanehalkı Bütçe Anketleri mikro veri seti kullanılmıştır. Hanehalkı Bütçe Anketi, Türkiye İstatistik Kurumu tarafından ilk olarak 1987'de yapılmış olup daha sonra 1994 yılında uygulanmıştır. 2002 yılından itibaren ise bütçe anketleri yıllık olarak uygulanmaktadır. 2002 yılında uygulanan Hanehalkı Bütçe Anketi, her ay değişen 800 hanehalkı ele alınarak yıl boyunca toplamda 9,600 örnek hanehalkına uygulanmıştır. 2003 yılında ise hanehalkı sayısı aylık 2,160'a çıkarılmış dolayısıyla yıl boyunca 25,920 örnek hanehalkına uygulanmıştır. 2004-2008 Hanehalkı Bütçe Anketleri ise her ay 720 , yll boyunca 8,640 örnek hanehalkına uygulanmıştır. 2009 yılından itibaren ise örneklem hacmi her ay 1,104 olup yil boyunca 13,248 hanehalkına anket uygulanmaktadır². 2002 Hanehalkı Bütçe Anketi’nin tahmin düzeyi Türkiye, kent ve kırsal ayrımına sahip olup, 2003 yılından itibaren kır-kent ayrımında 12 Düzey-1 bölgesi ve 26 Düzey- 2 bölgesi bazında tahminler üretilmesine izin vermektedir.

Hanehalkı Bütçe anketi ile hanehalkının sosyoekonomik durumu, hanehalkı bileşimi, fertlerin istihdam durumu ve elde ettikleri ylllk gelirler ile hanehalkının bir ay boyunca yaptığı alt gruplar bazındaki tüketim harcamalarına ilişkin mikro veriler derlenmektedir. Ayrıca, hanehalkı bireylerinin işgücü durumlarının yanı sıra; eğitim, yaş, cinsiyet, vs. gibi karakteristik özelliklerini de içermesi, anketin çalışma ekonomistleri tarafindan ikincil veri seti olarak kullanılmasına imkân tanımaktadır.

Hanehalkı Bütçe Anketlerinde, bireylerin eğitim seviyelerine, işgücündeki durumlarına ve elde ettikleri gelirlerin hangi kaynaklardan geldiğine dair bilgilerin yer alması sebebiyle, bu çalışmada, 2003-2010 yılları Hanehalkı Bütçe Anketleri mikro veri seti kullanılmıştır. Bahsi geçen yılların toplam gözlem sayısı 357,966 olup çalışmanın örneklemi en az lisans derecesine sahip 20 yaş üstü 18,067 katılımcıdan oluşmaktadır. Bu katılımcıların yaklaşık \% 5’i yüksek lisans ve üstü derecelere sahip kişilerdir. Kadın ve erkek ayrımında bakıldığında, erkeklerin \% 5’i (548 kişi), kadınların ise \% 4'ü (280 kişi) yüksek lisans ve üstü derecede eğitim almışlardır.

\section{Ampirik Uygulama}

Çalışmada öne sürülen hipotezlerin test edilmesine yönelik olarak farklı bağımlı ve bağımsız değişkenler belirlenmiş̧ir. Bağımlı değişken olarak bireysel performansın doğrudan bir göstergesi olarak düşünülen 'teşvik' değişkeni; bağımsız değişkenler olarak ise eğitim, yaş, cinsiyet, medeni durum kukla değişkenleri kullanılmıştır. Teşvik değişkeni dört adımda oluşturulmuştur. İlk olarak, para biriminden altı sıfır atılmasını dikkate almak adına; 2005 yılı öncesindeki prim ve bahşiş/ikramiye değişkenleri 1,000,000'a bölünmüştür. Bu değişkenlerin reel değerleri, 2003 yılı deflâtörü kullanılarak bulunmuştur. Ardından asıl teşvik değişkenini oluşturmak için prim ve bahşiş/ ikramiye değişkenlerinin değerleri toplanmıştır. Son

2 İkame yaklaşımı yerine cevapsızlık düzeltmesi uygulamasına geçilmesinin ardından örneklem sayısı artırılmıștır. 
olarak, analizlerde aykırı (outlier) değerlerin etkilerini asgariye indirmek için teşvik değişkeninin logaritması alınmıştır.

Aşağıda teşvik değişkenin nasıl hesaplandığı gösterilmiş (1-3 numaralı denklemler); akabinde, çalışma kapsamında test edilen denklem gösterilmiştir (4 numaralı denklem). 'Rprim' değişkeni reel primi, 'Rbahşiş' değişkeni ise reel bahşiş/ikramiye değiş̧kenini ifade etmektedir.

Rprim $=$ prim*deflatör(2003)

Rbahşiş= bahşiş*deflatör(2003)

Teşvik=Rprim + Rbahşiş

$\operatorname{Ln}($ Teşvik $)=\beta_{0}+\beta_{1} k a d \imath n+\beta_{2} M A \_P h d+\beta_{3}$ evli +

$\beta_{3}$ yaş $2529+\beta_{4}$ yaş3034 $+\beta_{5}$ yaş3539+ $\beta_{6}$ yaş $4044+$

$\beta_{7}$ yaş4549+ $\beta_{8}$ yaş $5054+\beta_{9}$ yaş5559+ $\beta_{10}$ yaş6064

$+\beta_{11}$ yaş65

(4) numaralı denklemde yer alan 'Kadın' kukla değişkeni, kadınlar için ' 1 ' değerini; erkekler için ise '0' değerini almaktadır. 'MA_Phd' kukla değişkeni, yüksek lisans ve üstü eğitim alanlar için ' 1 ' değerini; lisans eğitimi alanlar için ise ' 0 ' değerini almaktadır. 'Evli' kukla değişkeni, evli olanlar için ' 1 ' değerini; diğer medeni durumlar için ise ' 0 ' değerini almaktadır. 'Yaş2529' kukla değişkeni, 25-29 yaş grubunda olanlar için ' 1 ' değerini; diğerleri için ise ' 0 ' değerini almaktadır.

Parametreler en küçük kareler yöntemi kullanılarak tahmin edilmiştir. Tablo 3'teki birinci sütun, sadece 'kadın' bağımsız değişkeni kullanılarak tahmin edilen modeli göstermektedir. İkinci sütunda gösterilen ikinci modele 'MA_Phd' kukla değişkeni eklenmiştir. Ardından 'Evli' kukla değişkeni eklenerek üçüncü model elde edilmiştir. Dördüncü modele yaş gruplarını gösteren kukla değişkenler eklenmiştir. Beşinci ve altıncı modeller ise, kadın ve erkekler için ayrı ayrı tahmin edilen modelleri göstermektedir. Ayrıca, tablonun en altında gözlem sayıları, bağımsız değişkenlerin açıklama gücünü gösteren R-kare değerleri ve eldeki verileri kullanılarak elde edilen doğrusal regresyon katsayılar kestiriminin anakütle doğrusal modeline uyup uymadığını sınamak için kullanılan F-test sonucu verilmektedir. F-testi sonuçlarına ba- kıldığında eklenen değişkenlerin hepsinin anlamlı olduğu görülmüş ve bu nedenle bulgular, Model 4 üzerinden yorumlanmıştır.

Regresyon tahmin edilirken, temel olarak lisans veya yüksekokul mezunu 20 yaşındaki bekâr erkekler ele alınmıştır. Model 4’e bakıldığında, diğer değişkenler sabitken, yüksek lisans veya doktora yapmış olan bireylerin, en az yüksekokul veya lisans eğitimi almış olan bireylere göre daha yüksek teşvik aldıkları $(=0.95)$ görülmektedir (Tablo 3$)^{3}$. Bu bireyler, yaklaşı olarak 156 lira daha yüksek teşvik almaktadır. Bu bulgu, çalışmanın ilk hipotezini doğrulamakla birlikte; beşeri sermaye teorisini de destekler niteliktedir çünkü beşeri sermaye teorisine göre eğitim, bireylere yeni bilgi ve beceriler kazandırarak verimliliklerini arttırmakta; buna bağlı olarak, kazançlarını da olumlu yönde etkilemektedir (Mincer, 1993; Psacharopoulos ve Woodhall, 1994). Yaş değişkeninin etkilerine bakıldığında, 20 yaşındaki bireylere göre, 30-34. 3539 ve 40-44 yaş aralıklarındakilerin daha yüksek teşvik aldığ̣ (sırasıyla 25, 42, 39 lira) gözlemlenmiştir. Daha yukarı yaşlarda olmanın ise teşvik üzerinde bir etkisi yoktur. Bu bulgu, bireylerin en üretken yaşlarının orta yaş olduğunu göstermektedir.

Çalışmanın ikinci hipotezine dair bulguları yansıtan Model 5 (sadece kadınlar için olan model) ve Model 6’ya (sadece erkekler için olan model) bakıldığında, bireylerin yüksek lisans ve doktora derecesine sahip olduklarını gösteren MA_PHD değişkeninin katsayılarının örneklemdeki erkeklerde daha yüksek olduğu görülmektedir. Bu farkın istatistikî olarak anlamlı olup olmadığını görebilmek için Model 7 tahmin edilmiştir. Tablo 3’te görüldüğü üzere, MA_PHDxKADIN değişkenin önündeki katsayı istatistikî olarak sıfırdan farklı değildir; dolayısıyla da yüksek lisans veya doktora yapan kadınlar ile aynı seviyede eğitim almış erkeklerin teşvik primleri arasında anlamlı bir fark yoktur. Bu bağlamda, yüksek lisans ya da doktora derecesine sahip olmanın bireysel performans üzerindeki etkisinin, kadın ve çalışanlar arasında anlamlı bir fark göstermediği; dolayısıyla lisansüstü eğitimin performansa dayalı teşvikler açısından getirisinin kadın ve erkekler için benzer olduğu söylenebilir.

Çalışma kapsamında dikkat çeken ilginç bulgulardan biri, kadınlar için evli olup olmamanın alınan teşvik-

3 Çalışmanın modeli yarı logaritmik bir model olduğu için bulunan katsayılar direkt olarak yorumlanamamaktadır. Tahmin edilen parametreyi yorumlarken uygulanan formül: 


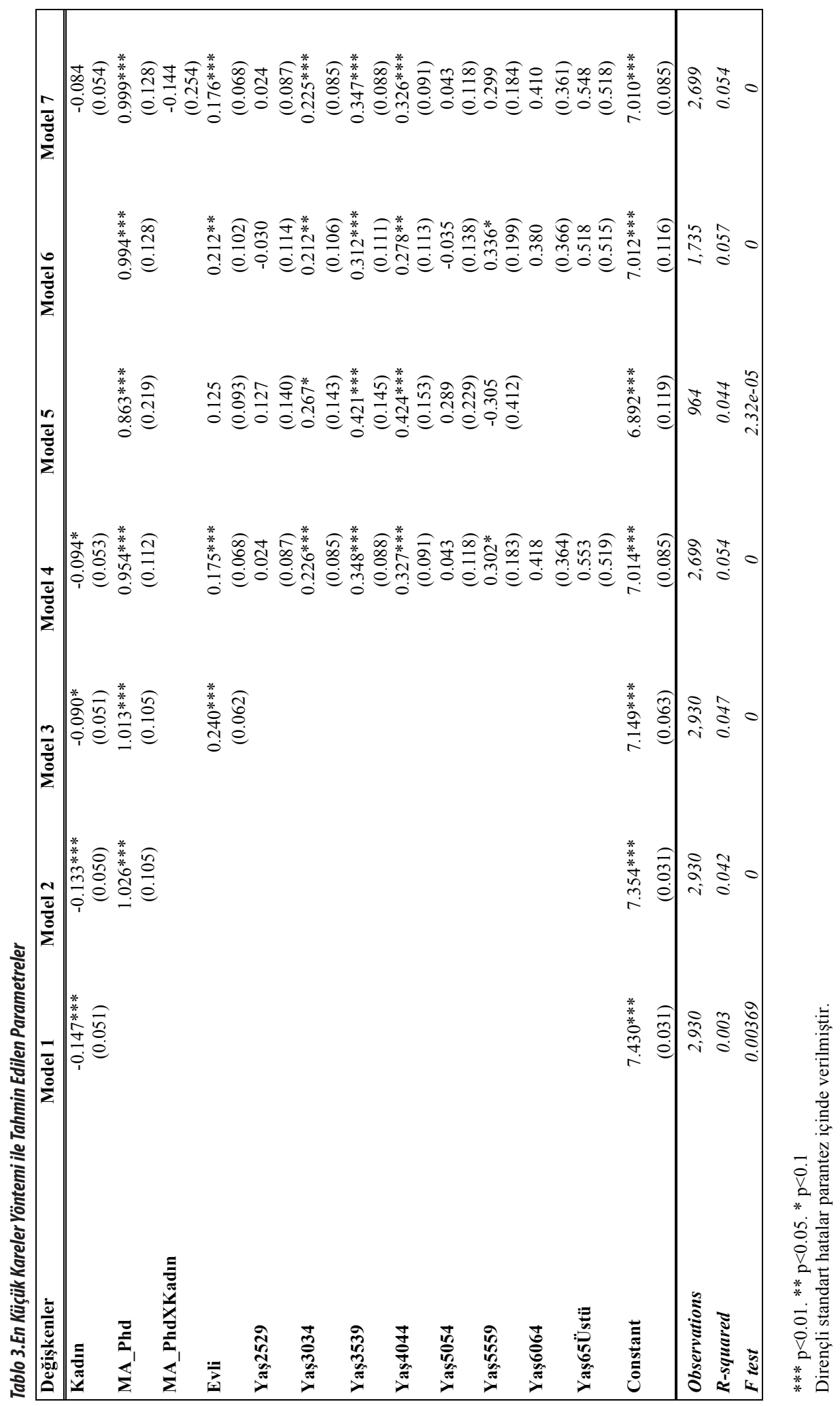


ler üzerinde bir etkisi yokken; erkekler için durumun farklı olmasıdır. Şöyle ki evli erkeklerin bekârlara göre daha yüksek teşvik aldığı gözlemlenmiştir. Evli erkekler, yaklaşık olarak 24 lira daha yüksek teşvik almaktadırlar. Bu durumun iki temel sebebi olabilir: Türk toplumunda var olan 'erkeklerin eve ekmek getiren kişi’ oldukları yargısı (Palaz, 2002), erkeklerin teşvik almak için daha çok çaba harcamalarına neden olabilir. Ayrıca, evli erkeklerin hayatlarının daha düzenli olması da işteki performanslarını olumlu yönde etkileyerek daha yüksek teşvik tedbirleriyle ödüllendirilmelerini sağlayabilir.

\section{Sonuç}

2003-2010 yılları Hane Halkı Bütçe Anketleri mikro veri seti kullanılarak yapılan analizler sonucunda, yüksek lisans ya da doktora derecesine sahip olan çalışanların performanslarının, bu derecelere sahip olmayan çalışanların performanslarından daha yüksek olduğu; dolayısıyla da, bu çalışanların diğer çalışanlara göre daha yüksek teşviklerle ödüllendirildikleri bulunmuştur. Bu bulgu, kişilerin beşeri sermayelerine yaptıkları yatırımın, işgücü piyasasında daha yüksek ücretler almalarını sağladığını savunan beşeri sermaye teorisini (Becker, 1964) destekler niteliktedir. Ayrıca, eğitimin bireylerin zekâ, bilgi ve beceri seviyeleri üzerindeki olumlu etkisine dikkat çeken önceki çalışmalara (Ceci, 1991; Neisser vd., 1996; Ng ve Fedman, 2009; Stark vd., 2011) paralel olarak; lisansüstü eğitimin bireylere, verilen görevlerin doğru bir şekilde yapılması için gerekli olan bildirime dayalı ve yöntemsel bilgiyi kazandırdığı ve buna bağlı olarak da performanslarını arttırdığı sonucuna varılmıştır. Daha yüksek eğitim seviyesine sahip bireylerin, derinlemesine ve analitik bilgiye dayanan kristal zekâlarının da yüksek olacağı (Ceci, 1991) ve bu durumun, bireysel performansa bağlı olarak alınan teşvik miktarlarını olumlu yönde etkileyeceği çalışmanın diğer çıkarımları arasında yer almaktadır. Buna göre, günümüzün sıkı piyasa ve rekabet koşulları içerisinde maddi anlamda daha iyi koşullara kavuşmak isteyen çalışanlar, lisans eğitimlerinin ardından lisansüstü eğitimlerine devam ederek beşeri sermayelerine yatırım yapma seçeneğini değerlendirmelidirler. Yüksek lisans ve ötesindeki derecelerin, bireylerin perfor- manslarını olumlu yönde etkileyerek gelecekteki kazançlarını arttırdığı, önceki çalışmalarda olduğu gibi (Caliskan, 2007; James ve Alsalam, 1993; Judge vd., 1995; Spilerman ve Lunde, 1991; Tansel, 1994; 2002) bu çalışmada da ortaya konulmuştur. Bununla birlikte, lisansüstü eğitimin çalışan performansı üzerindeki kanıtlanmış etkisi, işveren kurumların lisansüstü eğitimlerine devam etmek isteyen çalışanlarına destek olmalarını önemli kılmaktadır. Buna göre işverenler, yüksek lisans ya da doktora eğitimi alan/almak isteyen çalışanlarına iş saatleri ve/veya görev paylaşımı konusunda esneklikler sağlayarak bu çalışanların beşeri sermayelerine yaptıkları yatırıma destek olabilirler. Bu yatırım, orta ve uzun vadede, işveren kurumlardaki çalışan verimliliğini arttıracaktır.

Çalışmanın bir başka bulgusu da, yüksek lisans/doktora eğitimi almış olmanın performansa bağlı olarak alınan ücretler üzerindeki etkisinin erkekler ve kadınlar için anlamlı düzeyde farklı olmadığıdır. Önceki çalışmalar, Türkiye’de kadınların, işgücü piyasasında süreklilik gösteren bir cinsiyete dayalı ayrımcılıkla karşı karşıya olduğunu göstermiştir. Bu ayrımcılığın en önemli etkisi, erkek çalışanlarla aynı beşeri sermaye donanımına sahip kadın çalışanların, erkeklerden daha düşük ücret alması şeklinde ortaya çıkmaktadır. Bu çalışmada ise, eğitim-gelir ilişkisini cinsiyet temelli inceleyen önceki çalışmaların aksine, performansa bağlı olarak alınan teşvik tedbirleri söz konusu olduğunda cinsiyet ayrımcıllğının ortadan kalktığı gözlemlenmiştir. Bunun önemli bir nedeni, bireylerin kendi beşeri sermayelerine yaptıkları yatırımın kadın ve erkekler için benzer performans çıktıları doğurması ve performansin en temel göstergelerinden biri olarak kabul edilen teşvik tedbirlerinin dağıtımında, işverenler tarafından daha tarafsız ve görünür ölçütlerin dikkate alınması olabilir. Bir başka deyişle işverenler ya da karar verici diğer merciiler, performansa dayalı teşvikler söz konusu olduğunda; üretim-satış miktarı, firmaya kazandırılan müşteri sayısı, müşteri memnuniyeti gibi gözlemlenip ölçülebilen kıstasları dikkate aldıkları için cinsiyetler arası farklarla ilgili olası önyargılarının etkisinden arınırlar. Kadın ve erkek çalışanlara, ikramiye, prim ve bahşiş gibi teşvik tedbirlerini performansları ile doğru orantılı olarak verirler. Kadınların eğitim seviyeleri arttıkça, per- 
formansa dayalı ücretler bazındaki erkek ve kadın ayrımcılığının azalması, kadın çalışanların yüksek eğitime vermeleri gereken önemi ortaya koymakla birlikte; Türkiye’nin faklı bölgelerinde lisansüstü eğitime erişimi kolaylaştıracak devlet politikalarını destekleyen uygulamaları da (örn: uzaktan eğitim) gerekli kılmaktadır.

Yukarıda bahsi geçen bulguların çalışanların eğitim seviyeleri ile performansları arasındaki ilişkileri inceleyen ve bu ilişkiye cinsiyet temelli bir bakış açısı getirmeyi hedefleyen farklı çalışmalara katkıda bulunarak çeşitli kavramsal ve ampirik çalışmalara yön vereceği düşünülmektir. Gelecekteki çalışmalar, benzer bir model ışığında, lisansüstü eğitimin farklı performans göstergeleri (terfi hızı, kurum içerisindeki mevkii, yan ödenekler) üzerindeki etkisini incelemekle birlikte; bu etkinin, farklı yaş, kıdem ve deneyim seviyelerine sahip çalışanlarda nasıl farklılaştığını araştırabilir. Ayrıca, hanehalkı bütçe anketi soru formundaki sorulara ek olarak yukarıda bahsi geçen farklı performans göstergeleri ile ilgili bilgileri içeren yeni bir anket oluşturulup, Türkiye genelini temsil edecek bir örnekleme uygulanmadan önce, seçilen bölge ya da şehirlerde uygulanabilir. Bahsi geçen ankette, çalışanların performanslarını değerlendiren yöneticilerinden her bir çalışanın performans notları alınıp, çalışanların diğer bilgileri ile eşleştirilebilir. Sınırlı bir örnekleme uygulanacak olan bu anketler, bireylerin lisansüstü eğitim yoluyla beşeri sermayelerine yaptıkları yatırımın, iş performansları üzerindeki etkilerinin direk olarak incelenmesini sağlamakla birlikte; test edilen ilişkilerin Hanehalkına Bütçe Anketleri mikro veri seti kullanılarak yapılan analiz sonuçlarıyla paralellik gösterip göstermediğini anlamaya imkân tanıyacaktır. Bulgular paralellik gösterdiği takdirde, çalışmanın genellenebilirliği artmış olacaktır. Bununla birlikte, bölge düzeyindeki mikro veri setleri ya da anket formları kullanılarak yapılan çalışmalarda farklı sonuçlar elde edildiği takdirde bölge ya da şehir gruplarına özel birtakım sosyo-ekonomik koşulların incelemeye alınması düşünülebilir.

Bütün bunlara ek olarak, yüksek lisans/doktora eğitim almış olmanın performansa bağlı olarak alınan ücretler üzerindeki etkisinin meslek gruplarına göre farklı olup olmadığı sorusu da araştırmacıların çalış- mak isteyeceği bir konu olabilir. Bu araştırma kapsamında, bu sorunun incelenememesinin nedeni yüksek lisans/doktora yapan bireyler ait oldukları meslek gruplarına göre ayrıştırıldığında, her bir meslek grubundaki gözlem sayısının oldukça azalması ve bu durumun denklem tahminlerini imkânsızlaştırmasıdır. Buna ek olarak, bireylerin yüksek lisans/doktora yaptığı alanda çalışıp çalışmadıklarına bağlı olarak, performansı temel alan ücretlerinin değişip değişmediğinin de incelenmesi gerekmektedir. Bu çalışma kapsamında, bireylerin hangi alanda yüksek lisans/ doktora yaptıkları bilinmediği için bu soruya da cevap verilemiştir. Diğer bir araştırma sorusu ise bireylerin çalıştıkları işyerlerine ait bazı özelliklerin (örn: şirketin sermaye yapısı, büyüklüğü, vs.) performansa bağlı olarak alınan ücretler üzerinde etkisi olup olmadığıdır. Mevcut veride bireylerin çalıştıkları kurum/ kuruluşlara ait bilgilerin bulunmaması da bu çalışmanın kısıtlanmasına sebep olmuştur. Hanehalkı İşgücü Anketleri'nde bireylere yüksek lisans/doktora yaptıkları alan, çalıştıkları şirketlerin sermaye yapıları ve diğer şirket özellikleri sorulduğu takdirde, mevcut çalışmanın kısıtları büyük ölçüde ortadan kalkacaktır.

\section{Kaynakça}

Becker, G. (1964). Human Capital: A Theoretical and Empirical Analysis with Special Reference to Education. New York: Columbia University Press.

Bergmann, B. R. (1986). The Economic Emergence of Women. New York: Basic Books.

Blundell, R., Dearden, L., Meghir, C., Sianesi, B. (1999). Returns From Education and Training to the Individual, the Firm, and the Economy. Fiscal Studies, 20(1), 1-23.

Bowman, W. R., Mehay, S. L. (1999). Graduate Education and Employee Performance: Evidence From Military Personnel. Economics of Education Review, 18, 453-463.

Ceci, S. J. (1991). How Much Does Schooling Influence General Intelligence and Its Cognitive Components? A Reassessment of the Evidence. Developmental Psychology, 27, 703-722. 
Çalışkan, Ş. (2007). Eğitimin Getirisi (Uşak ili örneği). Süleyman Demirel Üniversitesi İktisadi ve İdari Bilimler Fakültesi Dergisi, 12(2), 235-252.

Çolak, Ö. F., Ardor, H. N. (2001). İşgücü Piyasasında Ayırımcıllk: Türkiye ve Seçilmiş Ülke Örnekleri. Ekonomik Yaklaşım,12(40), 89-112.

Engin, Y. (1996). Eğitim Üretim ve Verimlilik. Mercek, 4, 45-46.

Günay, D., Günay, A. (2011). 1933'den Günümüze Türk Yükseköğretiminde Niceliksel Gelişmeler. Yükseköğretim ve Bilim Dergisi, 1(1), 1-22.

Hunter, J. E., Hunter, R.F. (1984). Validity and Utility Alternative Predictors of Job Performance. Psychological Bulletin, 96, 72-98.

Judge, T. A., Cable, D.M., Boudreau, J.W., Bretz, R. D. (1995). An Empirical Investigation of the Predictors of Executive Career Success. Personnel Psycho$\log y, 48,485-519$.

Kanfer, R., Ackerman, P. L. (2004). Aging, Adult Development, and Work Motivation. Academy of Management Review, 29(3), 440-458.

Kasnakoğlu, Z., Dayığlu, M. (1997). Kentsel Kesimde Kadın ve Erkeklerin İşgücüne Katılımları ve Kazanç Farklılıkları (Women's Labor Force Participation and Earnings Differentials Between Genders İn Turkey). METU Studies, 24(3), 329-361.

Koçak, S. (1999). Gender Discrimination in the Turkish Labour Market, PhD Thesis in Social Sciences, De Montfort University, England.

Lawler, E. E., III. (1990). Strategic Pay. San Francisco: Jossey Bass.

Lawler, E. E., III. (1992). The Ultimate Advantage: Creating the High-Involvement Organization. San Francisco: Jossey Bass.

Lyness, K. S., Thompson, D. E. (1997). Above the glass ceiling? A comparison of matched samples of female and male executives. Journal of Applied Psychology, 82, 359-375.
Mincer, J. (1993). Studies in Human Capital. Cambridge: Edward Elgar.

Neisser, U., Boodoo, G. Bouchard, T.J., Boykin, A.W., Brody, N., Ceci, S.J., Halpern, D.F., Loehlin, J.C., Perloff, R., Sternberg, R.J., Urbina, S. (1996). Intelligence: Knowns and Unknowns. American Psychologist, 51, 77-101.

Ng, T.H.W., Feldman, D.C. (2009). How Broadly Does Education Contribute to Job Performance? Personnel Psychology, 62, 89-134.

Özcan, Y. Z., Özcan, M. K., Ücdoğruk, S. (2003). Wage Differences by Gender, Wage and Self-Employment in Urban Turkey. Journal of Economic Corporation, 24, 1-24.

Özpolat, A., Yildırım, M. (2009). In Developing Countries, Relationships Between Women's Education and Growth. EconAnadolu 2009: Anadolu International Conference in Economics, Eskişehir, Türkiye. Haziran 17-19.

Öztürk, N. (2005). İktisadi Kalkınmada Eğitimin Rolü. Sosyoekonomi, 1, 27-44.

Palaz, S. (2002). Türkiye’de Cinsiyet Ayırımcilığı Analizinde Neoklasik Yaklaşıma Karşı Kurumcu Yaklaşım: Eşitliği Sağlayıcı Politika Önerileri. http://sbe. balikesir.edu.tr/dergi/edergi/c6s9/makale/c6s9m5. pdf

Psacharopoulos, G., Patrinos, H. (2002). Returns to Investment in Education: A Further Update.The World Bank Policy Research Working Paper Series 2881.

Ree, M. J., Earles, J. A., Teachout, M. S. (1994). Predicting Job Performance: Not Much More Than g. Journal of Applied Psychology, 79(4), 518-524.

Rosenbaum, J. E. (1984). Career Mobility in A Corporate Hierarchy. Orlando, FL: Academic Press.

Sarı, R. (2002). Kazançlar ve Eğitim İlişkisi: İl Bazında Yeni Veri Tabanı ile Kanıt. ODTÜ Gelişme Dergisi, 29(3-4), 367-380. 
Schultz, T. W. (1971). Investment in Human Capital: The Role of Education and of Research. New York: Free Press.

Spilerman, S., Lunde, T. (1991). Features of Educational Attainment and Job Promotion Prospects. American Journal of Sociology, 97, 689-720.

Stark, E. (2008). Facing The Potential of an Aged Workforce and Reconciling Business Images of Peak Performance, Speed, and Innovation.Sixteenth annual meeting of the Institute of Behavioral and Applied Management, Orlando, FL. Ekim 2-4.

Stark, E., Poppler, P. P., Murnane, J. A. (2011). Looking for Evidence of Human Capital (Or the Lack Thereof) in College/University Degrees Held by Managerial Level Employees. Institute of Behavioral and Applied Management, 60-80.

Tansel, A. (1994). Wage Employment, Earnings and Returns to Schooling for Men and Women in Turkey. Economics of Education Review, 13(4), 305-320.

Tansel, A. (2002). Self-Employment, Wage-Employment, and Returns to Schooling by Gender in Turkey. D. Salehi-Isafhani, (Der.) Labor and Human Capital içinde, Reading, UK: Ithaca Press.
TÜİK (2012). Eğitim İstatistikleri.http://tuik.gov.tr/ PreTablo.do?alt_id=1018

Unay, C. (1982). Eğitimin İktisadi Kalkınma Üzerindeki Etkileri. İstanbul: AR BasımYayınDağıtım.

Üçdoğruk, S., Özcan, Y. Z., Özcan, M. K. (2003). Türkiye’de Gelişmişlik İndeksine Göre Seçilmiş İllerde Gelir Farklılıklarını Belirleyen Etmenler. Ekonomik Yaklaşım, 1, 29-57.

Ünal, L. I. (1993). Eğitimin Ekonomideki Rolü ve Türkiye ile İlgili Bulgular. III. İzmir İktisat Kongresi, 4-7 Haziran 1992, Sosyal Değişim ve Sosyal Gelişme Stratejileri, Ankara: DPT Yayını, 225-234.

Weatherly, L. (2003). Human Capital-The Elusive Asset. HRMagazine, 48(3), 1-9.

YÖK (2013). YÖK Üniversite Listesi. https://faaliyet. yok.gov.tr/KATALOG/raporlar/tumUnversitelereAitIletisimBilgileri.zul?raporTipi=xls 